\title{
Research on in vitro haploidization of heterozygotic breeding lines of tomato (Solanum lycopersicum L.)
}

\author{
Badania nad haploidyzacją in vitro heterozygotycznych lini hodowlanych pomidora \\ (Solanum lycopersicum L.)
}

\author{
Waldemar Kiszczak ${ }^{1 \oplus}$, Urszula Kowalska ${ }^{1 \oplus}$, Maria Burian ${ }^{2 \oplus}$
}

\author{
${ }^{1}$ Research Institute of Horticulture, Konstytucji 3 Maja 1/3, 96-100 Skierniewice, Poland, \\ ${ }^{2}$ Institute of Experimental Plant Biology and Biotechnology, Faculty of Biology, University of Warsaw, \\ Miecznikowa 1, 02-096 Warsaw, Poland, \\ $\triangle$ waldemar.kiszczak@inhort.pl
}

\begin{abstract}
Experiments were made in order to examin the influence of various factors on the induction of androgenesis in heterozygous breeding material of tomato. The factors like: length of buds the manner of sterilization, type and the composition of induction media, genotype and thermal shock were included in conducted experiments. Most of all sterile cultures with the highest number of anther-derived callus were obtain by applying $2,5 \%$ calcium hypochlorite for 5 minutes. Anther-derived calli was obtained in 9 breeding lines from 18 used genotypes. The induction medium with the composition based on $\mathrm{B}_{5}$ medium with the addition of $750 \mathrm{mg} \mathrm{L}^{-1}$ calcium chloride and $100 \mathrm{~g} \mathrm{~L}^{-1}$ sucrose proved to be the best for inducing androgenesis. The addition of thidiazuron and NAA to this medium in the following season and silver nitrate in the other experiminet improved the efficiency of this process, which was depended on the genotype. Despite the lack of statistically significant differences, the highest number of anther-derived calli was obtained when anthers were cooled for 2 days in $+4^{\circ} \mathrm{C}$ in the refrigerating chamber.
\end{abstract}

\begin{abstract}
Key words: genotype, microsporogenesis, phytohormones, sterilization, thermal shock, tomato
Przeprowadzono doświadczenia, w których zbadano wpływ różnych czynników na indukcję androgenezy u heterozygotycznych linii hodowlanych pomidora. Poddano analizie następujące czynniki: długość pąka, sposób wyjaławiania materiału roślinnego, genotyp, rodzaj i skład pożywki indukcyjnej oraz szok termiczny. Wykazano, że długość pylnika jest dobrym zewnętrznym markerem faz rozwojowych mikrospor pomidora. Stosując 2,5\% podchloryn wapnia przez 5 minut uzyskano najwięcej czystych kultur i największą ilość kalusa pochodzącego z tych kultur. Z 18 użytych linii hodowlanych u 9 linii hodowlanych uzyskano kalus pochodzenia pylnikowego. Skład pożywki indukcyjnej $\mathrm{B}_{5}$ z $750 \mathrm{mg} \mathrm{L}^{-1}$ chlorku wapnia i $100 \mathrm{~g} \mathrm{~L}^{-1}$ sacharozy okazał się najlepszy dla wywołania androgenezy. Dodatek thidiazuronu oraz kwasu naftylo-1-octowego do tej pożywki w następnym sezonie oraz azotanu srebra w innym doświadczeniu podniósł efektywność tego procesu, który jak wykazaliśmy, uzależniony był od genotypu. Mimo braku statystycznie istotnych różnic zaobserwowano najwyższą ilość kalusa, gdy pylniki chłodzono przez 2 doby w $+4{ }^{\circ} \mathrm{C}$.
\end{abstract}

Słowa kluczowe: fitohormony, genotyp, mikrosporogeneza, sterylizacja, szok termiczny, pomidor

Abbreviations: NAA: 1-naphthaleneacetic acid; 2,4-D: 2,4-Dichlorophenoxyacetic acid; TDZ: thidiazuron

\section{Introduction}

Androgenesis is the process of plant development from microspores or young pollen grains. In higher plants such process can be induced by the culture of anthers or isolated microspores on the different media in in vitro conditions. As a result of the application of various stimuli, microspores can change their development pathway and form directly or indirectly calli on an embryo, which in the end is converted to a haploid plant or doubled haploid (Heberle-Bors and Reinert 1979, Wang et al. 2000, Shariatpanahi et al. 2006). In the conventional heterozygotic breeding process the selection of homozygous lines is conducted on the large population of plant material for many years. One of the solutions to this problem may be the application of induced androgenesis, because the recessive features are already disclosed in the regeneration stage of in vitro cultures. This allows for the quick and effective selection, in which less amount of valuable plant material is used.

The amount and the range of experiments on the gametic embryogenesis of tomato is very limited (Bal and Abak 2007). The first reports on the induction of androgenesis in tomato come from the year 1971, when Sharp and the team applied so-called nurse cultures. In their study, 
a few haploid cells were obtained as a result of the incubation of microspores in the presence of anthers. The greater number of this cells was obtained by Zamir et al. (1980). Five years later, Dunwell (1985) reported that he obtained an embryogenic callus and embryos in anther cultures. The following authors: Jaramillo and Summers (1990); Summers et al. (1992) have examined and determined the influence of microspore development phases, the presence and the lack of light and gelling agents on the efficiency of androgenesis in tomato. Shtereva et al. (1998) examined the effect of the various microspore development stages and the various growing conditions of donor plants on the efficiency of androgenesis process. In the same year, Zagorska et al. (1998) published the result of the conducted studies, in which they demonstrated a correlation between the genotype and the efficiency of androgenic callus formation in tomato. In the following article, the same authors described an influence of the growth environment of donor plants, the microspore development stages, the size of anthers and the media composition on the androgenesis process (Shtereva et al. 1998). In 1999, Brasileiro et al. analysed the effect of growth regulators on the induction of androgenesis in tomato anther cultures. In the year 2007, Segui'-Simarro and Nuez obtained only a few proembryoids in tomato microspore cultures, whereas in anther cultures the androgenic callus was induced and then regenerated into plants. Zagorska et al. (2004) obtained regenerants and presented their morphological, cytological, biochemical and genetic characteristics. Nevertheless, Segui'-Simarro et al. (2011) stated that until the time of publication of their work there were a lack of reliable and standardized production methods of tomato DH lines with the use of gametic embryogenesis. Moreover, authors presented that despite of several dozen years of conducting research only two research teams published the results, in which regenerated tomato plants were obtained (Zagorska et al. 2004; Segui'-Simarro and Nuez 2007). In 2015, Julião et al. still recognized the necessity of conducting studies on the standardization of methods of obtaining double haploid lines of tomato through gametic embryogenesis. The main reason for this is the strong genotype determination, which is limiting the ability to induce androgenesis in tomato. Therefore, it is necessary to confirm the ability of inducing androgenesis for each genotype and determine the optimal parameters for particular factors enabling the induction of androgenesis. Experiments conducted in the Research Institute of Horticulture, Skierniewice, Poland were executed in order to determine the optimal parameters for androgenesis induction in heterozygotic breeding material of tomato and the ability of individual plants for androgenesis. The influence of the course of microsporogenesis, sterilization methods, the genotype, induction media composition and anther thermal treatments on the efficiency of androgenesis in tomato anther cultures were examined. This is the first stage of the studies which result in the formation of homozygotic androgenic lines of tomato from the valuable heterozygotic breeding material, which is suitable for the breeding process of modern varieties.

\section{Material and methods Plant material}

Plant material included heterozygotic lines of tomato delivered by cooperating Breeding and Seed Company - POLAN Sp. z o.o. in Cracow, Poland. The influence of the genotype was examined in 18 breeding lines. The effect of the remaining factors were analysed on the selected lines, which were chosen randomly, according to the following methodical description.

Seedlings of tomato were planted in 20 litre containers ( 2 per container) with substrate consisiting of $3: 1(\mathrm{v} / \mathrm{v})$ soil and sand and placed in a greenhouse under controlled growth conditions at $18^{\circ} \mathrm{C}$ during the day and $16^{\circ} \mathrm{C}$ at night, with a 16 hour photoperiod. Plants were brought to the early phase of flowering in order to collect anthers for further experiments.

\section{Examination of the course of microsporogenesis}

Observations of the course of microsporogenesis were conducted. We assessed the correlation between the length of the bud and the phase of microspore development.

Anthers were isolated with the use of dissecting needle. Next, anthers were crushed on the slide with the drop of acetocarmine and closed with the cover slide. The course of microsporogenesis was analysed under a microscope (light microscope, Eclipse E200, Nikon). The following haploid cells development stages were distinguished: 1. tetrad of microspores with separate calosic cell walls, that is four identical microspores formed after meiotic division of mother cell; 2 . released microspore in the polarized phase - where the shifted nuclei is located in the dense cytoplasm, and in the late phase - where the nuclei is localized near the sporoderm, surrounded with the vacuolated cytoplasm; 
3. binuclear pollen grains where in the early phase both nuclei are localized in the centre part of pollen grains and in the late phase, in which two cells were identified: small generative cell and large vegetative cell. The percentage of microspores/pollen grains in the all specific development phase was defined in tomato buds and divided into 5 groups in respect of the length of the buds as follow: 5,6 , $7,8,9 \mathrm{~mm}$. Five buds were analysed for each tested group. From 70 to 100 cells were observed in each bud.

\section{Buds disinfection methods}

The following disinfection methods of buds were applied: (A) $-5 \mathrm{~min}$. in 70\% ethanol, rinsed three times in sterile distilled water; (B) $-5 \mathrm{~min}$. in $2.5 \% \mathrm{Ca}(\mathrm{ClO})_{2}$, rinsed four times in sterile distilled water; (C) - $15 \mathrm{sec}$. in $70 \%$ ethanol, $5 \mathrm{~min}$. in $2.5 \% \mathrm{Ca}(\mathrm{ClO})_{2}$, rinsed five times in sterile distilled water.

\section{The influence of the medium on androgenesis induction}

Anther cultures were induced according to the methodology elaborated for carrot in Institute of Vegetable Crops (Górecka et al. 2005). Anthers from buds of $9-8 \mathrm{~mm}$ length were placed on the media solidified with agar $6 \mathrm{~g} \mathrm{~L}^{-1}$ on the basis of: modified $\mathrm{B}_{5}$ medium with increased to $750 \mathrm{mg}$ $\mathrm{L}^{-1}$ content of $\mathrm{CaCl}_{2}$ and supplemented with $0.1 \mathrm{mg}$ $\mathrm{L}^{-1}$ 2,4-Dichlorophenoxyacetic acid (2,4-D), $0.1 \mathrm{mg}$ $\mathrm{L}^{-1}$ 1-Naphthaleneacetic acid (NAA) and $100 \mathrm{~g}$ $\mathrm{L}^{-1}$ of sucrose (B5-I medium); N6 medium (Chu et al. 1975) with the addition of $0.1 \mathrm{mg} \mathrm{L}^{-1} 2,4-\mathrm{D}$ and $\mathrm{Cm}$ medium with the addition of kinetin and 2,4-D (2 $\mathrm{mg} \mathrm{L}^{-1}$ each) (Sibi et al.1979); the amount of $30 \mathrm{~g} \mathrm{~L}^{-1}$ sucrose was added to the last two media. The $\mathrm{pH}$ of the prepared media was adjusted to 5,8. Additionally, we investigated the effect of $5 \mathrm{mg} \mathrm{L}^{-1}$ Thidiazuron (TDZ) and $1 \mathrm{mg} \mathrm{L}^{-1} \mathrm{NAA}$ in modified $\mathrm{B}_{5}$ medium (B5-II medium) and also the influence of $5 \mathrm{mg} \mathrm{L}^{-1} \mathrm{AgNO}_{3}$ in both tested media - B5-I and B5-II, used for androgenesis induction. Flasks with anthers were placed in the dark at $+35^{\circ} \mathrm{C}$. After 8 days flasks were exposed to continuous light with an intensity of $30 \mu \mathrm{mol} \cdot \mathrm{m}^{-2} \cdot \mathrm{s}^{-1}(16 / 8$ hours of light photoperiod) while maintaining the temperature of $+25^{\circ} \mathrm{C}$ (Ercan and Sensoy 2011).

\section{The influence of the genotype on the efficiency of androgenesis}

In experiments analysing the impact of the genotype, anthers of 18 breeding lines were placed on medium on the basis of B5 (Gamborg et al. 1968) containing $5 \mathrm{mg} \mathrm{L}^{-1} \mathrm{TDZ}$ and $1 \mathrm{mg}$ $\mathrm{L}^{-1}$ NAA. The amount of $30 \mathrm{~g} \mathrm{~L}^{-1}$ sucrose was added to the last two media. The $\mathrm{pH}$ of the prepared media was adjusted to 5,8 . Initiated cultures were conducted in the same way as the next experiment. In which anthers from buds of $9-8 \mathrm{~mm}$ length were placed in flasks containg tested media. Next the anthers were placed in the dark at $+35^{\circ} \mathrm{C}$. After 8 days flasks were exposed to continuous light with an intensity of $30 \mu \mathrm{mol} \cdot \mathrm{m}^{-2} \cdot \mathrm{s}^{-1}(16 / 8$ hours of light photoperiod), while maintaining the temperature of $+25^{\circ} \mathrm{C}$ until the embryos appeared.

\section{The effect of thermal shock}

The impact of low temperature on the androgenesis efficiency from anther cultures was examined on B5-I medium. Flasks with anthers were subjected to the following time and temperature algorithms: $-1 .+4^{\circ} \mathrm{C}$ for $24 \mathrm{~h} ; 2 .+4^{\circ} \mathrm{C}$ for $48 \mathrm{~h} ; 3 .+10^{\circ} \mathrm{C}$ for 24 $\mathrm{h} ; 4 .+10^{\circ} \mathrm{C}$ for $48 \mathrm{~h}$. The controls were flasks with anthers, which were placed in standard conditions described in the above experiment.

\section{Statistical analyses}

Each flask contained 48 anthers. The individual flask was counted as a repetition. The number of repetitions in each experiment ranged from 10 to 15 flasks and depended on genotype and the availability of anthers in a given season. The obtained data were analysed using multivariate ANOVA (MANOVA), nonparametric analyses, such as Kruskal-Wallis at an adopted level of significance of $\alpha=0.05$. Statistical analyses were performed using the Statistica 8.0 software package for Windows (Statsoft Inc., Tulsa, OK).

\section{Results \\ Studies on the course of microsporogenesis}

During the analysis of the correlation between the length of the buds and the course of microsporogenesis it was established that the most of all microspores in the polarized phase $(68 \%)$ was found in buds with a length of $9 \mathrm{~mm}$, while $82 \%$ of binuclear pollen grains in the early phase was located in buds with a length of $8 \mathrm{~mm}$ (Tab.1).

\section{Disinfection methods}

The highest percentage of clean cultures was obtained with the use of the B disinfection method, which had a translation into the largest number of anther-derived calli from all tested disinfection methods. In conversion to 100 plated anthers 51.05 of anther-derived calli were obtained. While the lowest number was obtained using $\mathrm{C}$ disinfection 
method (7.32 on 100 plated anthers). The highest after the application of A disinfection method, 11.30 percentage of contaminated anthers was obtained on 100 plated anthers were obtained (Tab. 2).

Table 1

The haploid cells at particular development phases in respect of the different length of anthers of breeding line No. 44

\begin{tabular}{|c|c|c|c|c|c|c|c|c|c|c|}
\hline \multirow{4}{*}{$\begin{array}{l}\text { Anther length } \\
\quad(\mathrm{mm})\end{array}$} & \multicolumn{10}{|c|}{ Development phase } \\
\hline & \multirow{2}{*}{\multicolumn{2}{|c|}{ Tetrades }} & \multicolumn{4}{|c|}{ microspores } & \multicolumn{4}{|c|}{ binuclear pollen grains } \\
\hline & & & \multicolumn{2}{|c|}{ early } & \multicolumn{2}{|c|}{ late } & \multicolumn{2}{|c|}{ early } & \multicolumn{2}{|c|}{ late } \\
\hline & No & $\%$ & No & $\%$ & No & $\%$ & No & $\%$ & No & $\%$ \\
\hline 5 & 36 & 100 & 0 & 0 & 0 & 0 & 0 & 0 & 0 & 0 \\
\hline 6 & 0 & 0 & 27 & 100 & 0 & 0 & 0 & 0 & 0 & 0 \\
\hline 7 & 0 & 0 & 37 & 88 & 5 & 12 & 0 & 0 & 0 & 0 \\
\hline 8 & 0 & 0 & 0 & 0 & 0 & 0 & 18 & 82 & 4 & 18 \\
\hline 9 & 0 & 0 & 0 & 0 & 34 & 68 & 16 & 32 & 0 & 0 \\
\hline
\end{tabular}

Table 2

The efficiency of three disinfection methods of flower buds before establishing anther cultures of tomato

\begin{tabular}{|c|c|c|c|c|}
\hline \multirow{2}{*}{$\begin{array}{l}\text { Disinfectionme- } \\
\text { thod }\end{array}$} & \multirow{2}{*}{$\begin{array}{c}\text { Number of plated } \\
\text { anthers }\end{array}$} & \multirow{2}{*}{$\begin{array}{c}\% \text { of contaminated } \\
\text { anthers }\end{array}$} & \multicolumn{2}{|c|}{ The number of } \\
\hline & & & $\begin{array}{l}\text { obtained } \\
\text { calli }\end{array}$ & calli/per 100 anthers \\
\hline A & 2145 & 20.90 & 242 & $11.30 b^{*}$ \\
\hline $\mathrm{B}$ & 429 & 7.20 & 219 & $51.05 \mathrm{a}$ \\
\hline $\mathrm{C}$ & 560 & 13.20 & 41 & $7.32 \mathrm{~b}$ \\
\hline
\end{tabular}

* Combinations located in the same homogeneous group (with the same letter) do not differ statistically at a significance level of $\alpha=0.05$. Kruskal-Wallis test

Table 6

The influence of the genotype of $\mathbf{1 8}$ breeding lines on androgenesis efficiency in anther cultures of tomato

\begin{tabular}{ccccc}
\hline \multirow{2}{*}{ No. } & Breeding line & \multicolumn{4}{c}{ The number of } \\
\cline { 3 - 5 } & 2 & plated anthers & $\begin{array}{c}\text { obtained } \\
\text { anther-derived callus }\end{array}$ & $\begin{array}{c}\text { anther-derived callus/per 100 } \\
\text { anthers }\end{array}$ \\
\hline 1 & 3 & 74 & 5 & $7.14 \mathrm{~b}$ \\
2 & 4 & 76 & 4 & $5.40 \mathrm{~b}$ \\
3 & 9 & 74 & 12 & $10.53 \mathrm{~b}$ \\
4 & 11 & 73 & 2 & $16.21 \mathrm{~b}$ \\
5 & 13 & 73 & 4 & $2.74 \mathrm{~b}$ \\
6 & 16 & 79 & 10 & $5.48 \mathrm{~b}$ \\
7 & 18 & 67 & 2 & $12.66 \mathrm{~b}$ \\
8 & 43 & 76 & 193 & $2.98 \mathrm{~b}$ \\
9 & 8 & 67 & 0 & $253.94 \mathrm{a}$ \\
10 & 10 & 67 & 0 & $0.00 \mathrm{c}$ \\
11 & 14 & 67 & 0 & $0.00 \mathrm{c}$ \\
12 & 15 & 84 & 0 & $0.00 \mathrm{c}$ \\
13 & 17 & 84 & 0 & $0.00 \mathrm{c}$ \\
14 & 22 & 77 & 0 & $0.00 \mathrm{c}$ \\
15 & 29 & 74 & 0 & $0.00 \mathrm{c}$ \\
16 & 41 & 73 & 0 & $0.00 \mathrm{c}$ \\
17 & 42 & 73 & $0.00 \mathrm{c}$ \\
18 & located in the same homogeneous & group & (with the same letter) \\
\hline Combinations & not differ statistically
\end{tabular}
at a significance level of $\alpha=0.05$. Kruskal-Wallis test 


\section{The influence of the genotype}

The most of all anther-derived callus among all tested lines was obtained in line No. 43 (253.94 of anther-derived callus/per 100 anthers) (Fig. 1). The least, that is 2.74 of anther-derived callus/per 100 anthers, was obtained in the line No. 11. Anther -derived callus was not obtained in 9 from among all 18 tested breeding lines (Tab. 6).

\section{The influence of the medium on androgenesis induction}

Three different media were tested in the first stage of the studies. The highest number, that is 11,3 of anther-derived callus per 100 anthers, was obtained using B5-I-100 medium, while only 0.05 of anther-derived callus per 100 anthers was received on N6-1 medium. Whereas androgenesis was not successfully induced on the third tested medium (Tab. 3). In the second experiment, the addition of TDZ and NAA to the B5 medium (B5-II medium) resulted in the increased number of anther-derived callus. On this medium, 15 of anther-derived callus per 100 plated anthers were obtained. Whereas 9.8 of anther-derived callus per 100 anthers were obtained on B5-I-100 medium (Tab. 4). In the following experiment, the addition of $\mathrm{AgNO}_{3}$ to B5-I-100 did not increase the number of obtained anther-derived callus. On the medium without this component, 0.3 calli per 100 plated anthers was obtained while 0.2 of anther-derived callus per 100 anthers was obtained on the medium with the addition of this component. While $\mathrm{AgNO}_{3}$ was added to the B5-II medium, the highest number of callus was obtained, i.e. 0.5 calli per 100 plated anthers. While 0.4 of anther-derived callus per 100 anthers was obtained on the medium without this component (Tab. 5).

\section{The effect of thermal shock}

In the experiment on the influence of the thermal shock, the highest number of anther-derived callus (16.7) per 100 plated anthers waere obtained when anthers were placed in the temperature of $+4^{\circ} \mathrm{C}$ for $48 \mathrm{~h}$. The least effective conditions, in which anthers were placed, were $48 \mathrm{~h}$ in the temperature of $+10^{\circ} \mathrm{C}$ where 5.0 of anther-derived callus were obtained per 100 plated anthers (Tab. 7).

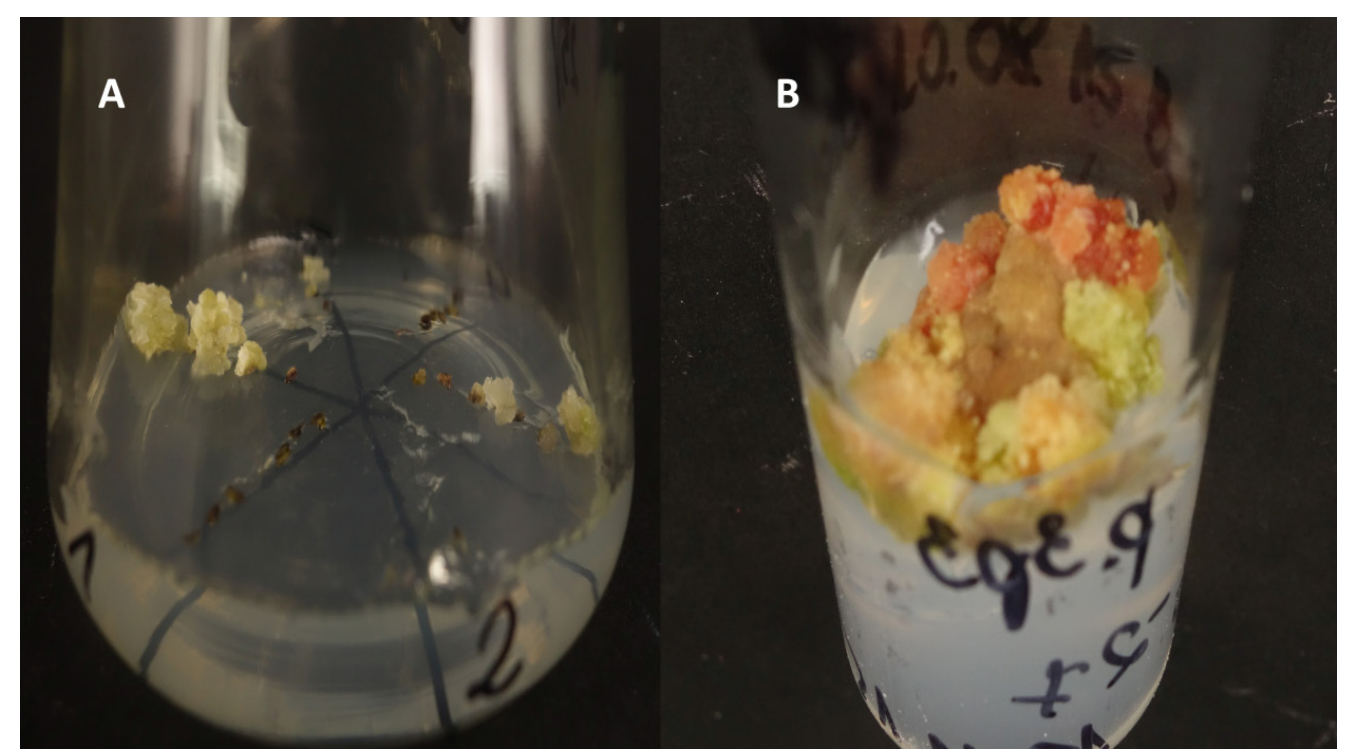

Fig.1 Anther culture of tomato: A - anther-derived callus, B - proliferating anther-derived callus in the test tube 
Table 3

The influence of the medium on androgenesis efficiency in tomato line No. 44

\begin{tabular}{|c|c|c|c|}
\hline \multirow[b]{2}{*}{ Medium } & \multicolumn{3}{|c|}{ The number of } \\
\hline & $\begin{array}{l}\text { plated } \\
\text { anthers }\end{array}$ & $\begin{array}{c}\text { obtained } \\
\text { anther-derived callus }\end{array}$ & $\begin{array}{l}\text { anther-derived callus/per } \\
\qquad 100 \text { anthers }\end{array}$ \\
\hline${ }^{1} \mathrm{~B} 5-\mathrm{I}$ & 2145 & 242 & $11.30 \mathrm{a}^{*}$ \\
\hline${ }^{2} \mathrm{~N} 6-1$ & 1914 & 1 & $0.05 b$ \\
\hline${ }^{3} \mathrm{Cm}$ & 1142 & 0 & $0.00 \mathrm{c}$ \\
\hline $\begin{array}{l}{ }^{1} \mathrm{~B} 5-\mathrm{I} \text { mediu } \\
{ }^{2} \mathrm{N6}-1 \text { medi } \\
{ }^{3} \mathrm{Cm} \text { mediur } \\
{ }^{*} \text { Combina } \\
\text { do not diffe }\end{array}$ & $\begin{array}{l}\text { ntained: } \\
\text { ontained } \\
\text { tained: } \\
\text { located } \\
\text { istically }\end{array}$ & $\begin{array}{l}m g L^{-1} 2,4-D \text { and } 0.1 \mathrm{n} \\
\mathrm{mg} \mathrm{L} \mathrm{L}^{-1} 2,4-D \\
\mathrm{mg} \mathrm{L} \mathrm{L}^{-1} 2,4-D \text { and } 2.0 \mathrm{~ms} \\
\text { he same homogeneous } \\
\text { significance level of } \alpha\end{array}$ & $\begin{array}{l}L^{-1} N A A \\
\text { 'kinetin } \\
\text { roup (with the same letter) } \\
0.05 . \text { Kruskal-Wallis test }\end{array}$ \\
\hline
\end{tabular}

Table 4

The influence of two combinations of various phytohormones on the efficiency of androgenesis in tomato line No. 44 in the first season.

\begin{tabular}{cccc}
\hline & \multicolumn{2}{c}{ The number of } \\
\cline { 2 - 4 } Medium & $\begin{array}{c}\text { plated } \\
\text { anthers }\end{array}$ & $\begin{array}{c}\text { obtained } \\
\text { anther-derived callus }\end{array}$ & $\begin{array}{c}\text { anther-derived callus/per 100 } \\
\text { anthers }\end{array}$ \\
\hline${ }^{1}$ B5-I & 174 & 17 & $9.80 \mathrm{a}^{*}$ \\
${ }^{2}$ B5-II & 180 & 27 & $15.00 \mathrm{a}$ \\
\hline
\end{tabular}

*Combinations located in the same homogeneous group (with the same letter) do not differ statistically at a significance level of $\alpha=0.05$. Kruskal-Wallis test

${ }^{1}$ B5-I medium contained: $0.1 \mathrm{mg} \mathrm{L}^{-1} 2,4-D$ and $0.1 \mathrm{mg} \mathrm{L}^{-1} \mathrm{NAA}$

${ }^{2}$ B5-II medium with: $5 \mathrm{mg} \mathrm{L} \mathrm{L}^{-1} \mathrm{TDZ}$ and $1 \mathrm{mg} \mathrm{L}^{-1} \mathrm{NAA}$

Table 5

The influence of $\mathrm{AgNO}_{3}$ in various combinations of $\mathrm{B5}$ medium on androgenesis efficiency in tomato line No. 44 in the second season

\begin{tabular}{cccc}
\hline \multirow{2}{*}{ Medium } & The number of \\
\cline { 2 - 4 } & plated anthers & $\begin{array}{c}\text { obtained } \\
\text { anther-derived callus }\end{array}$ & $\begin{array}{c}\text { anther-derived callus/per } \\
100 \text { anthers }\end{array}$ \\
\hline B5-I & 682 & 2 & $0.30 \mathrm{a}^{*}$ \\
$\mathrm{~B} 5-\mathrm{I}+\mathrm{AgNO}_{3}$ & 647 & 1 & $0,15 \mathrm{~b}$ \\
$\mathrm{~B} 5-\mathrm{II}$ & 757 & 3 & $0.40 \mathrm{a}$ \\
$\mathrm{B} 5-\mathrm{II}-\mathrm{Ag} \mathrm{NO}_{3}$ & 599 & 3 & $0.50 \mathrm{a}$ \\
\hline
\end{tabular}

*Combinations located in the same homogeneous group (with the same letter) do not differ statistically at a significance level of $\alpha=0.05$. Kruskal-Wallis test

Table 7

The influence of the application of thermal shock on the efficiency of anther cultures of tomato breeding line no. 4081

\begin{tabular}{cccc}
\hline & \multicolumn{2}{c}{ The number of } \\
\cline { 2 - 4 } Thermal shock & anthers & anther-derived callus & $\begin{array}{c}\text { anther-derived callus/per } 100 \\
\text { anthers }\end{array}$ \\
\hline Control & 60 & 6 & $10.00 \mathrm{a}$ \\
$24 \mathrm{~h}+4^{\circ} \mathrm{C}$ & 60 & 7 & $11.70 \mathrm{a}$ \\
$48 \mathrm{~h}+4^{\circ} \mathrm{C}$ & 60 & 10 & $16.70 \mathrm{a}$ \\
$24 \mathrm{~h}+10^{\circ} \mathrm{C}$ & 60 & 9 & $15.00 \mathrm{a}$ \\
$48 \mathrm{~h} 10^{\circ} \mathrm{C}$ & 60 & 3 & $5.00 \mathrm{~b}$ \\
\hline
\end{tabular}

*Combinations located in the same homogeneous group (with the same letter) do not differ statistically at a significance level of $\alpha=0.05$. Kruskal-Wallis test 


\section{Discussion}

According to the literature data, the most suitable for androgenesis induction in crop plants are microspores in the late phase or early- bicellular pollen grain (Kiszczak et al. 2005, Dubas et al. 2010, Soriano et al., 2013). Many authors indicate, that the bud length is a good morphological indicator of microspore development phases and thus it can be considered as a valid marker of anther usability for anther cultures (Moraes et al., 2008, Parra -Vega et al., 2013). Julião et al. (2015) with the use of flow cytometer confirmed a correlation between the microspre development phases in tomato anthers and the length of the bud, in which they were located. Jaramillo (1988) indicated, on the basis of the literature data, the correlation between the bud length and the length of the anthers located inside. Author observed over $50 \%$ of microspores in the mononuclear phase in anthers with a length of $1,6 \mathrm{~mm}$, which corresponds with buds with the length of approximately $3 \mathrm{~mm}$. The observations were made with the use of the direct cytological method. The same method was applied in our studies, where over $50 \%$ of microspores in the desirable phase were observed in the buds with the length of $8-9 \mathrm{~mm}$. In presented work, in buds with the length of $8 \mathrm{~mm}$ was more than $80 \%$ of bicellular pollen.. Previously, Segur'Simarro and Nuez (2007) and also Asoliman et al. (2007) demonstrated the differences in the course of microsporogenesis in buds of the same length between cultivars. Julião et al. (2015), with the use of indirect cytological method that is flow cytometry, confirmed this fact for the length of the tomato buds. Depending on the cultivar, the optimal length of the bud was in the range of 1-6 mm. Buds collected directly from the plant, as every type of explants introducing to the in vitro cultures, must be subjected to the disinfection process. This stage, as described by Kouakou et al. (2015), is a great challenge for obtaining the aseptic cultures of all plant species. In our experiments, aseptic cultures were obtained in case of all tested methods of bud disinfection. The combination of $70 \%$ ethanol with the disinfection in the sodium hypochlorite was applied successfully by various authors (Jaramillo 1988., Zagorska et al., 2004). Julião et al. (2015) used $1 \%$ calcium hypochlorite solution combined with the former disinfection in $70 \%$ ethanol. The lower androgenesis efficiency was obtained by using ethanol combined with calcium hypochlorite in comparison to the method, where only $2.5 \%$ calcium hypochlorite solution was applied, which constitute a progress in the procedure preparation. Successful sterilization allowed to establish the experiment, in which the influence of the genotype on androgenesis efficiency was analysed. The studies conducted by Zagorska and coauthors (1998) clearly indicate that the genotype is the very important factor determining the induction of androgenesis. In their experiments, androgenic callus was obtained in 53 from among 85 genotypes used in the studies. In the presented studies, callus was obtained in 9 breeding lines, which is a half of the 18 lines used in our experiments. Shtereva and Atanassova (2001) were able to induce embryogenesis in all wild mutants of tomato, but the efficiency of this process was different depending on the genotype. Similarly to our studies, 253.94 callus structures per 100 anthers were obtained in the most embryogenic line no. 43 , while only 2.74 were observed in the less embryogenic breeding line. The influence of the genotype in our studies was determined with the use of the medium on the basis of the B5 with the addition of $100 \mathrm{~g} \mathrm{~L}^{-1}$ sucrose (B5-1), Shtereva et al. (1998) did not include this medium in their studies. Authors analysed media on the basis of N6, LS (Linsmaier and Skoog 1965), DYI (Gresshoff and Doy 1974) and MS (Murashige and Skoog 1962. The most effective in their studies proved to be the media on the basis of MS, whereas the efficiency of applying N6 media was not given. In our studies, the N6 medium proved to be the less effective in comparison to the B5 medium. In 2007, Segui'-Simarro i Nuez applied NLN medium for androgenesis induction in tomato, while Corral-Martı'nez et al. (2011) used MS medium. All above-mentioned authors obtained homogeneous androgenic calli on anthers. Therefore, the comparison of the efficiency of our androgenic cultures with the results given by other authors, who present only the percentage share of anthers generating the callus, is inadequate. The efficiency of the best medium (B5) in our experiments is higher in comparison to the media applied by Shtereva et al. (1998), Segur'-Simarro (2007), Corral-Martínez et al. (2011).

On our third tested media $(\mathrm{Cm})$ androgenic callus was not obtained, while Sibi et al. (1979) obtained androgenic embryos on this medium in pepper that belong to the same family as tomato. Plant growth regulators perform an important role in the culture media, including TDZ and NAA. Not many literature reports on the application of TDZ for androgenesis induction were found. Only few reports relate to the application of this cytokinin in the process of somatic embryogenesis. Kaparakis and Alderson (2003) used TDZ for the induction of somatic embryogenesis in tomato seedlings. Authors 
demonstrated that TDZ negatively affected this process. However, somatic

embryogenesis due to the principal reasons, that is the formation of embryo or callus by somatic cell divisions, is the different process from gametic, where embryos are formed by a change in the development path of the gametic cell in generative line. The positive effect of TDZ on the androgenesis in pepper, that is the same representative of the family as tomato, was noted by Khan et al. (2006) in their studies. Also in our studies the application of this cytokinin in the induction medium allowed to obtain a higher number of androgenic callus structures of tomato. It has to be noted, that TDZ in the concentration of $5 \mathrm{mg} \mathrm{L}^{-1}$ was added in the combination with $1 \mathrm{mgL}^{-1} \mathrm{NAA}$. Previously, the same concentration of NAA in the medium was applied by Brasileiro et al. 1999, who demonstrated the positive effect of NAA on the quantity of the androgenic callus in tomato. Whereas, the highest number of androgenic callus was obtained by Asoliman et al. (2007) with the application of $0.5 \mathrm{mg} \mathrm{L}^{-1} \mathrm{NAA}$ in anther cultures. Also in pepper, androgenesis was successfully induced by the addition of NAA (Cheng et al. 2013). Authors determined that the significantly lower concentration of $0.2 \mathrm{mg} \mathrm{L}^{-1} \mathrm{NAA}$ was the most effective. Also another component, $\mathrm{AgNO}_{3}$ was used in the studies on androgenesis in pepper (Buyukalaca et al. 2004, Nowaczyk et al. 2006, Popova et al. 2016). Whereas, in 2007 only Seguí-Simarro and Nuez successfully applied silver nitrate for the induction of androgenic callus on the medium for the preculture of tomato anthers. In our experiments on the effect of the silver nitrate on the number of generating callus structures of tomato, we obtained results that indicate its positive effect in medium containing also abovementioned plant growth regulators. In the previous season, the higher number of anther-derived callus was obtained during the studies concerning the effect of only TDZ and NAA on the efficiency of androgenesis process. Therefore, such inconclusive results can enrich the literature data on the application of $\mathrm{AgNO}_{3}$, however the srudies on this topic require further examination.

The efficiency of androgenesis can be elevated by the selection of the optimal thermal shock parameters. Shtereva et al. (1998) in their studies showed a positive influence of low temperature $\left(+4^{\circ} \mathrm{C}\right)$ applied for $48 \mathrm{~h}$ on the anther cultures of tomato. However, authors applied this stress with the combination of gamma radiation. In presented studies, also the same algorithms of temperature and time proved to be the most effective among all tested variants. Popova et al. (2016) examined the effect of low temperature shock on the efficiency of androgenesis in pepper anther cultures by placing anthers also in $+4^{\circ} \mathrm{C}$ for 24 or $48 \mathrm{~h}$. Authors obtained the highest efficiency in the control conditions, where low temperature was not applied. In our studies, the lowest efficiency was observed in the control conditions in comparison to the above-mentioned temperature conditions. Noteworthy also the high number of anther-derived callus were obtained after applying the temperature of $+10^{\circ} \mathrm{C}$ for $24 \mathrm{~h}$. The high androgenesis efficiency obtained after applying this variant of low temperature treatment allows this algorithm to be recommended for the induction of androgenesis in anther cultures of tomato.

\section{Conclusions}

1. Length of the bud is a good indicator for determining the developmental phases of tomato microspores.

2. The most effective sterilization method is the application of $2.5 \% \mathrm{Ca}(\mathrm{ClO})$, for $5 \mathrm{~min}$., next rinsing four times in sterile distilled water.

3. The genotype is the primary factor determining the ability of plants to induce androgenesis in tomato.

4. A high factor of induction of androgenesis in tomato is obtained on B5 medium containing $750 \mathrm{mg} \mathrm{L}^{-1}$ calcium chloride and $100 \mathrm{~g}$ $\mathrm{L}^{-1}$ sucrose.

5. The addition of $5 \mathrm{mg} \mathrm{L}^{-1} \mathrm{TDZ}, 1 \mathrm{mg} \mathrm{L}^{-1} \mathrm{NAA}$ and $5 \mathrm{mg} \mathrm{L}^{-1} \mathrm{AgNO}_{3}$ to the $\mathrm{B} 5$ medium increases the efficiency of androgenesis.

6. The cooling process of anthers for 2 days in $+4^{\circ} \mathrm{C}$ increase the efficiency of androgenesis in tomato.

\section{References}

Asoliman, S.S., T.A. Ismail, M.A. Zaki and E.S. Amer, (2007). Genetisc studies on tomato anther culture. Factors affecting induction of androgenesis in tomato anther culture. African Crop Science Conference Proceedings 8:759-768.

Bal, U., Abak K. (2007). Haploidy in tomato (Lycopersicon esculentum Mill.): a critical review. Euphytica 158:1-9.

Brasileiro, A.C.R., Willadino, L., Carvalheira G.G., Guerra, M. (1999). Callus induction and plant regeneration of tomato (Lycopersicon esculentum CV. IPA 5) via anther culture. Ciência Rural 29 (4): 619-623.

Buyukalaca, S., Comlekcioglu N., Abak K., Ekbic E., Kilic, N. (2004). Effects of silver nitrate and donor plant growing conditions on production of pepper (Capsicum annuum L.) ha-ploid embryos via anther culture. Eur. J. Hortic. Sci. 69 (5): 206-209. 
Cheng, Y., Ma R., Jiao Y., Qiao N., Li, T. (2013). Impact of genotype, plant growth regulators and activated charcoal on embryogenesis induction in microspore culture of pepper (Capsicum annuum L.). S. Afr. J. Bot. 88:306-309.

Chu, C.C., Wang C.C., Sun C.S., Hsu K.C., Yin K.C., Chu C.Y.,. Bi, F.Y. (1975). Establishment of an efficient medium for anther culture of rice through comparative experiments on the nitrogen sources. Sci. Sin. 18:659-668.

Corral-Martı'nez, P., Nuez, F., Segu1'-Simarro, J.M. (2011). Genetic, quantitative and micro-scopic evidence for fusion of haploid nuclei and growth of somatic calli in cultured ms 1035tomato anthers. Euphytica 178:215-228.

Dubas, E., Wędzony M., Petrovska B., Salaj J., Żur, I. (2010). Ercan Cell structural reorganization during induction of androgenesis in isolated microspore cultures of triticale $(\times$ Triticosecale WITTM.). Acta Biol. Cracov. Bot. 52/1:73-86.

Dunwell, J.M. 1 (985). Haploid cell cultures. In Plant cell culture: A practical approach. R.A. Dixon (Eds.), IRL Press Ltd., Boca Raton, FL. 21-36

Ercan, N., Sensoy, F.A. (2011). Androgenic responses of different pepper (Capsicum annuum L.) Biyoloji Bilimleri Arastirma. Dergisi 4 (2): 59-61.

Gamborg, O.L., Miller R.A, Ojima, K. (1968). Nutrient requirements of suspension cultures of soybean root cells. Exp. Cell Res. 50:148-151.

Górecka, K., Krzyżanowska D., Kiszczk W., Górecki, R. (2005). Embryo induction in anther culture of Daucus carota L. Veg. Crop. Res. Bull. 63:25-32.

Gresshoff, P.M., Doy, C.H. (1974). Development and differentiation of haploid Lycopersicon esculentum (tomato). Planta 107:161-170.

Heberle-Bors, E., Reinert. J. (1979). Androgenesis in isolated pollen cultures of Nicotiana tabacum: Dependence upon pollen development. Protoplasma 99 (3): 237-245.

Jaramillo, J. (1988). Anther culture in the tomato (Lycopersicon esculentum Mill) callus and plantlet production studies. Retrospectives theses and dissertation. Iowa State University pp: 1-225.

Jaramillo, J., Summers, W. (1990). Tomato anther callus production: Solidifying agent and concentration influence induction of callus. J. Am. Soc. Hortic. Sci. 115:1047-1050.

Julião, S.A., Carvalho, C.R., Silva, T.C.R., Koehler, A.D. (2015). Multiploidy occurrence in tomato calli from anther culture. Afr. J. Biotechnol. 14 (40): 2846-2855.

Kaparakis, G., Alderson, P.G. (2003). Influence of high concentrations of cytokinins on the production of somatic embryos by germinating seeds of tomato, aubergine and pepper. J. Horti. Sci. Biotech. 77 (2): 86-190.

Khan, H., Siddique, I., Anis, M. (2006). Thidiazuron induced somatic embryogenesis and plant regeneration in Capsicum annuum. Biol. Plant. 50 (4): 789-792.
Kiszczak, W., Górecka, K., Krzyżanowska, D., Kowalska, U. (2005). Size of flower buds in carrot (Daucus carota 1.) as an indicator of a stage of microspore-genesis and its suitability for induction of androgenesis. Veg. Crop. Res. Bull. 62:81-90.

Kouakou, L., Doubi, T.S., Koffi, K.K., Kouassi, K.I., Kouakou, T.H., Baudoin, J.P., Zoro bi, I.A. (2015). Androgenic potential and anther in vitro culture of Lagenaria siceraria (Molina) Standl an edible-seed cucurbit. Int. J. Biol. Chem. Sci. 4:1779-1789.

Linsmaier, E.M., Skoog, F. (1965). Organic growth factor requirements of tobacco tissue cultures. Physiol Plant. 18:100-127.

Moraes, A.P., Bered, F., Carvalho, F.I.F., Kaltchuk-Santos, E. (2008). Morphological markers for microspore developmental stage in maize. Braz. Arch. Biol. Technol. 51 (5): 911-916.

Murashige, T., Skoog, F.A., 1962 Revised medium for rapid growth and bioassays with tobacco tissue cultures. Physiol. Plant. 15: 473-497.

Nowaczyk, P., Kisiała, A., Olszewska, D. (2006). Induced androgenesis of Capsicum frutescens L. Acta Physiol. Plant. 28 (1): 35-39.

Parra-Vega, V., Gonzalez-Garcia, B., Segui-Simarro, J.M. (2013). Morphological markers to correlate bud and anther development with microsporogenesis and microgametogenesis in pepper (Capsicum annuum L.). Acta Physiol. Plant. 35:627-633.

Popova, T., Grozeva, S., Todorova, V., Stankova, G., Anachkov, N., Rodeva, V. (2016). Effects of low temperature, genotype and culture media on in vitro androgenic answer of pepper (Capsicum annuum L.). Acta Physiol. Plant. 38:273-282.

Segui'-Simarro, J.M., Nuez, F. (2007). Embryogenesis induction, callogenesis, and plant regeneration by in vitro culture of tomato isolated microspores and whole anthers'. $J$. Exp. Bot. 58 (5): 1119-1132.

Segui'-Simarro, J.M., Corral-Mart1'nez, P., Parra-Vega, V., Gonza'lez-Garci'a, B. (2011) Androgenesis in recalcitrant solanaceous crops. Plant Cell Rep. 30:765-778.

Shariatpanahi, M.E., Bal, U., Heberle-Bors, E., Touraev, A. (2006). Stresses applied for the reprogramming of plant microspores towards in vitro embryogenesis. Physiol. Plant. 127:519-534.

Sharp, W. R., Dougall D. K., Paddock, E. F. (1971) Haploid plantlets and callus from immature

pollen grains of Nicotiana and Lycopersicon. Bull. Torrey bot. Club, 98: 219-222.

Shtereva, L.A., Zagorska, N.A., Dimitrov, B.D., Kruleva M.M., Oanh, H.K. (1998. Induced androgenesis in tomato (Lycopersicon esculentum Mill) II. Factors affecting induction of androgenesis. Plant Cell Rep. 4:312-317.

Shtereva, L., Atanassova, B. (2001). Callus induction and plant regeneration via anther culture in mutant tomato 
(Lycopersicon esculentum Mill.) lines with anther abnormalities. Isr. J. Plant Sci. 49 (3): 203-208.

Sibi, M., Vaulx R.D., Chambonnet, D. (1979). Obtaining haploid plants by in vitro androgenesis in red pepper (Capsicum annuum L.). Annales de l'Amelioration des Plantes, 29:583-606.

Soriano, M., Li H., Boutilier, K. (2013). Microspore embryogenesis: establishment of embryo identity and pattern in culture. Plant Reprod. 26:181-196.

Summers, W.L., Jaramillo J., Bailey, T. (1992). Microspore developmental stage and anther length influence the induction of tomato anther callus. Hortic. Sci. 7:838-840.

Wang, M., van Bergenm S., Duijnl, B. (2000). Insights into a key developmental switch and its importance for efficient plant breeding. Plant Physiol. 124:523-530.

Zagorska, N.A., Shtereva, A., Dimitrov, B.D., Kruleva, M.M. (1998). Induced androgenesis in tomato (Lycopersicon esculentum Mill.). Influence of genotype on androgenetic ability. Plant Cell Rep. 17: 968-973.

Zagorska, N.A., Shtereva, L.A., Kruleva, M.M., V.G. Sotirova, D.L. Baralieva and B.D. Dimitrov. (2004). Induced androgenesis in tomato (Lycopersicon esculentum Mill.). Characterization of the regenerants. Plant Cell Rep. 22:449-456.

Zamir, D., Kedar, J.N. (1980). Anther culture of male-sterile tomato (Lycopersicon-Esculentum MILL) mutants. Plant. Sci. Lett. 17 (3): 353-361. 